\title{
STUDIES ON THE WASTEWATER TREATMENT USING MODIFIED DOWN FLOW HANGING SPONGE (DHS) PILOT AND ITS APPLICATION
}

M. A. Wasel ${ }^{1}$, R. S. Farg ${ }^{1}$, A. S. El- Tabl ${ }^{2}$, A. M. Mahmoud ${ }^{1}$, A. M. Radwan ${ }^{3}$, K. S. Sarhan ${ }^{2}$ and A. Ezzat ${ }^{1}$

${ }^{1}$ Chemistry Department, Faculty of Science,Al-Azhar University, Cairo, Egypt.

${ }^{2}$ Chemistry Department, Faculty of Science, Menoufia University, Menoufia, Egypt.

${ }^{3}$ Sector Head of Laboratories in Qaluobia, Company for Water and Wastewater.

*Corresponding author: rabefarag191@yahoo.com

\begin{abstract}
In this paper the Modified Down Flow Hanging Sponge (DHS) reactor will be a good water treatment technology in the near future. It was used for excellent removal of notorious heavy metals, organic pollutants and harmful microbes. The reactor has advantages like low cost, ease of use and satisfaction level. In order to achieve these objectives, treatment scheme has been investigated. It consists of mixing a chelator with wastewater in different concentrations followed by a Down flow hanging sponge (DHS) reactor. The residual values of heavy metals are (Mn)amount decreases from $1 \mathrm{ppm}$ to zero ppm (100\%) after $60 \mathrm{~min}$.,(Fe)decreases from $0.997 \mathrm{ppm}$ to zero ppm (100\%) after $60 \mathrm{~min}$. (Cd) decreases from $0.901 \mathrm{ppm}$ to zero ppm (100\%) after 60 $\mathrm{min}$. (Cu)decreases from $1.1 \mathrm{ppm}$ to zero ppm (100\%) after $60 \mathrm{~min}$. $(\mathbf{P b})$ decreases from $1.004 \mathrm{ppm}$ to zero ppm (100\%) after $60 \mathrm{~min}$. (Ni)decreases from $0.922 \mathrm{ppm}$ to $0 \mathrm{ppm}(100 \%)$ after $60 \mathrm{~min}$. The results show that removals of fecal coliforms were achieved. From the results of DHS effluent, fecal coliforms decreased from $5.2 \times 10^{6}$ to 200 and the overall removal efficiency of fecal coliforms is $(99.99 \%)$ at $37 \mathrm{C}^{\circ}$.
\end{abstract}

Keywords: DHS reactor, chelator, heavy metal, fecal coliforms.

\section{INTRODUCTION}

Water is the most important and essential component on the earth for vital activities of living beings. Unfortunately, water quality from water resources is deteriorating continuously due to geometrical growth of population, industrialization, civilization, domestic, and agricultural activities, and other geological and environmental changes[1-3]. Therefore, water pollution has become a serious issue in the present scenario, affecting all living creatures, household, recreation, fishing, transportation, and other commercial activities[4-6]. The government authorities, scientists and academicians are worried and serious on this issue. Thousands of organic, inorganic, and biological pollutants have been reported as water contaminants [7].

Some of them have severe aspect results and toxicities with some being lethal and carcinogenic[8-10]. Those pollutants are very risky for aquatic conditions and the atmosphere of the earth as a whole. a few heavy metals are notorious water pollution with high toxicity and carcinogenicity. ${ }^{[11]}$ steel ions such as cadmium, chromium, mercury, selenium and lead, and so on have critical toxicities [12-15] at higher attention than the permissible restriction, [6]. cobalt causes vomiting, nausea, asthma, and carcinoma. except, cobalt is also chargeable for thyroid, gastrointestinal and liver problems. ${ }^{[16-18]}$ zinc is required for the increase of human beings, however high concentrations more than the permissible restriction $[3.0 \mathrm{mg} / \mathrm{L}]$ motive negative increase and mental fever [19-21] except, nitrate, sulfate, phosphate, fluoride, chloride, and oxalate have also some risky consequences. for example, excessive attention of nitrate consequences into blue toddlers 'disease (methemoglobin) in children [22].

Alternatively, it's far famous that, fluorosis is because of excessive degrees of fluoride in water [23] it has been mentioned that, excessive concentrations of other anions inclusive of sulfate, phosphate, chloride, oxalate, and so forth. alternate water taste [6]. Many organic pollutants had been observed in distinct water 
resources. these belong to various instructions which includes insecticides, fertilizers, hydrocarbons, phenols, plasticizers, biphenyls, detergents, oils, greases, prescription drugs, etc. $[23,24,25]$

The aspect outcomes and toxicities of those contaminants were formerly said [24,26, 27] .The one-of-a-kind sorts of microbes present in wastewater may be responsible for numerous sicknesses. the dangerous microbes are virus, bacteria, fungi, algae, amoebas, and planktons. those water pollutants stay either in soluble, colloidal, or in suspended form. these microbes are responsible for causing numerous ailments known as waterborne illnesses [28, 29]. Because of those kinds of pollution, the floor and groundwater at some places of the sector are infected, being undeserving for ingesting purposes. via 2020, the worldwide populace is anticipated to reach as much as 7.9 billion, ${ }^{[30]}$ and due to this the sector can be below highquality water scarcity. therefore, the removal of these pollutants from contaminated water is taken into consideration a pressing need for imparting ailment-free health to our society ${ }^{[30]}$.

The DHS post treatment system is designed for utility in growing nations as it yields effective energy balance and produces much less quantity of extra sludge. the principle of this system is using polyurethane sponge as a medium to preserve biomass. the concept is truly much like that of trickling filter, besides that the packing cloth is sponge, that may avoid area of more than $90 \%$, resulting in a huge boom in entrapped biomass and leads for that reason to longer solid retention time (SRT). as the sponge in DHS isn't always submerged and freely hung/positioned inside the air, oxygen gets dissolved into the wastewater because it flows down and therefore there may be no want of aeration or any other energy enter to the gadget. moreover, production of extra sludge from DHS turns into negligible as longer SRT provides ample time for autolysis of sludge in the system itself.

Wastewater is trickled from the pinnacle of the reactor and purified through microorganisms retained each outside and inside of the sponge media because the wastewater flows vertically down through the reactor. the gadget confirmed removal efficiency always over $95 \%$ for unfiltered biochemical oxygen demand (BOD), $80 \%$ for unfiltered-chemical oxygen demand and $70 \%$ for suspended solids. furthermore, excess sludge production from DHS turned into negligible as a consequence getting rid of secondary sludge that turned into difficult. A pilot-scale DHS $\left(0.38 \mathrm{~m}^{3}\right.$, volume of sponge) for treating municipal sewage turned into investigated.

\section{MATERIALS and METHODS}

\subsection{Down Flow Hanging Sponge (DHS) System}

The DHS module column as proven under includes four identical segments linked vertically, each section is prepared with $25 \mathrm{~L}$ of polyurethane foam (PF) wrapped with plastic material randomly allotted in the whole reactor. the DHS device is manufactured from percent, with a capacity of $0.3 \mathrm{~m}^{3}$ and has an inner diameter of $0.6 \mathrm{~m}$. the height of the reactor is $0.88 \mathrm{~m}$. the reactor will be full of PF which represents $34 \%$ of the whole liquid reactor volume. the characteristics of the PF (sponge) are as follows: floor region $256 \mathrm{~m}^{2} / \mathrm{m}^{3}$, density $30 \mathrm{~kg} / \mathrm{m}^{3}$, void ratio 0.9 , and pore size of 0.63 $\mathrm{mm}$. the whole extent of the PF could be $100 \mathrm{~L}$ Fig (1).

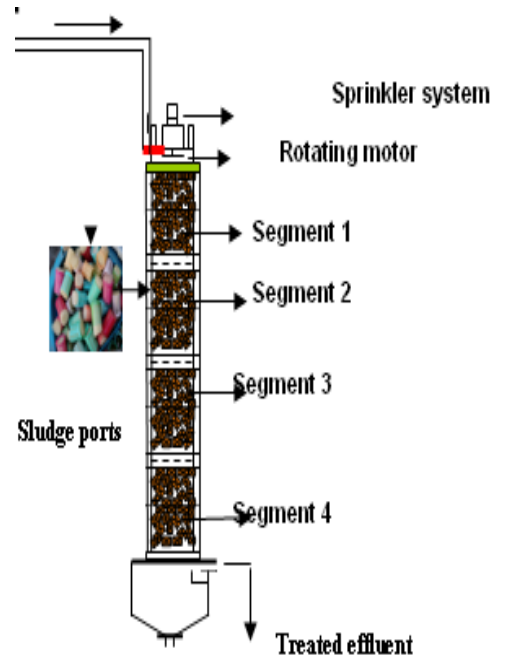

Fig. (1) DHS system

The size of the used sponge (PF) (cylindrical form) is $27 \mathrm{~mm}$ peak $\times 4 \mathrm{~mm}$ diameter. The wastewater effluent may be 
flowed by gravity to the distributor it really is positioned at the pinnacle of the DHS module and can be circled at $15 \mathrm{rpm}$. chemical parameters along with COD, BOD, TSS, TDS, $\mathrm{No}_{2}$ and $\mathrm{No}_{3}$ are monitored at retention time $6 \mathrm{~h}$ and $3 \mathrm{~h}$ consistent with APHA (2005) "popular methods for the exam of water and wastewater".

\subsection{Synthesis of the Organic Chelator}

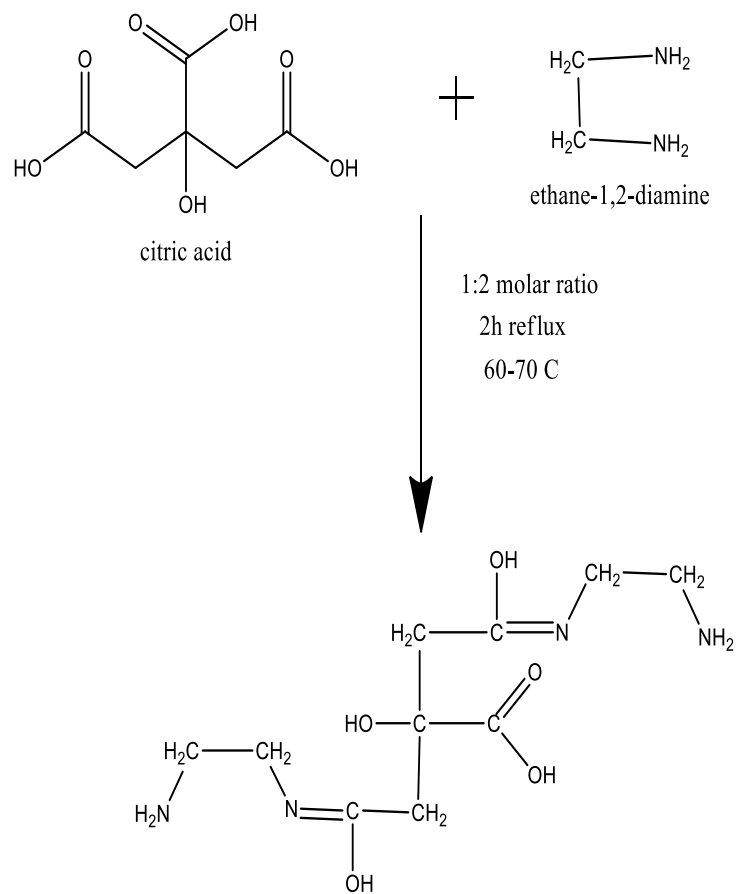

(S,Z)-4-((2-aminoethyl)imino)-2-((E)-2-((2-aminoethyl)imino)-2-hydroxyethyl)-2,4dihydroxybutanoic acid
Synthesis of the chelator: Citric acid (20.0 g, $1.04 \mathrm{~mol}$ ) was boiled in methanol for $1 \mathrm{~h} .5$ drops of conc. $\mathrm{H}_{2} \mathrm{So}_{4}$ were added, and continuously refluxed to $3 \mathrm{~h} .(18.0 \mathrm{~g})$ of ethylene diamine was added. the combination become refluxed with stirring for $3 \mathrm{~h}$ and the white precipitate fashioned was washed with methanol and dried in air. the practice and the shape of the chelator are represented in Figs. (2) and (3).<smiles>NCCN=C(O)CC(O)(CC(O)=NCCN)C(=O)O</smiles>

Chemical Formula: $\mathrm{C}_{10} \mathrm{H}_{20} \mathrm{~N}_{4} \mathrm{O}_{5}$

Exact Mass: 276.14

Molecular Weight: 276.29

$\mathrm{m} / \mathrm{z}: 276.14(100.0 \%), 277.15(11.2 \%), 278.15(1.6 \%), 277.14(1.5 \%)$ Elemental Analysis: C, 43.47; H, 7.30; N, 20.28; O, 28.95

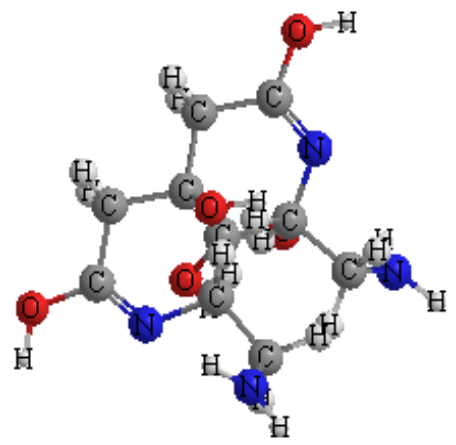

Fig (2\&3): Structure of the chelator and 3D.

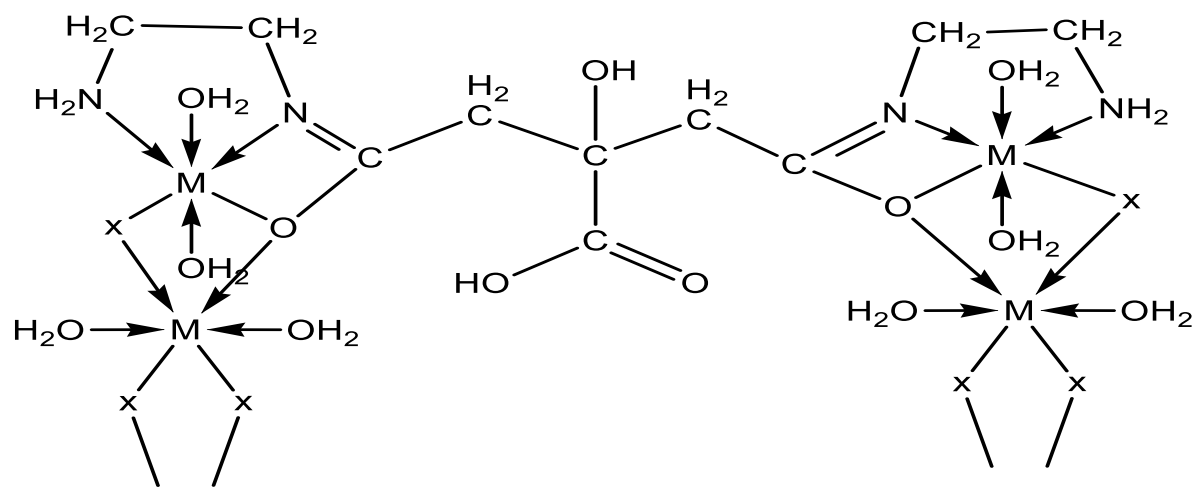

Fig (4): structure of suggested metal complexes.

$\mathrm{M}=\mathrm{Cu}$ (II), Ni (II), Fe (II), Mn (II), Cd (II), Pb (II). $\quad \mathrm{X}=(\mathrm{OAc})$ or $\mathrm{NO}_{3}$. 


\subsection{Element Analysis}

complexes via IR as in Figs. (5 - 11) and

The analysis of the organized ligand and its ${ }^{1}$ HNMR spectrum as in Fig. (12).

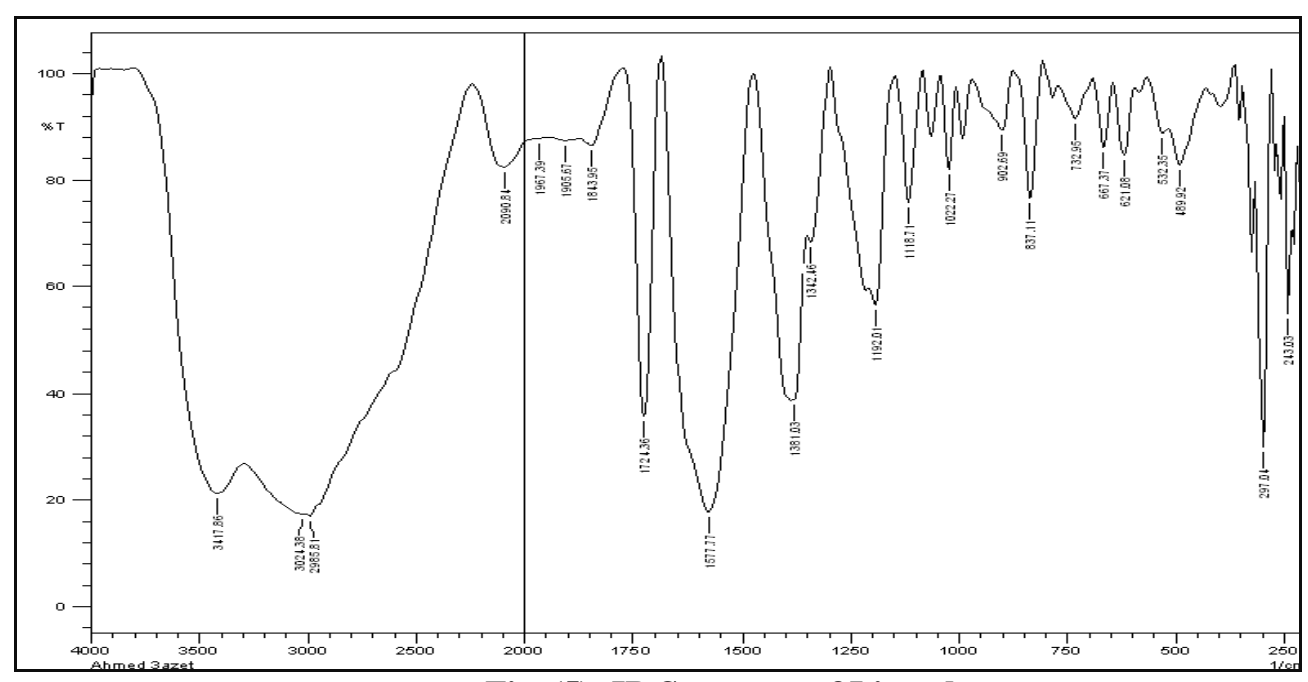

Fig. (5): IR Spectrum of Ligand

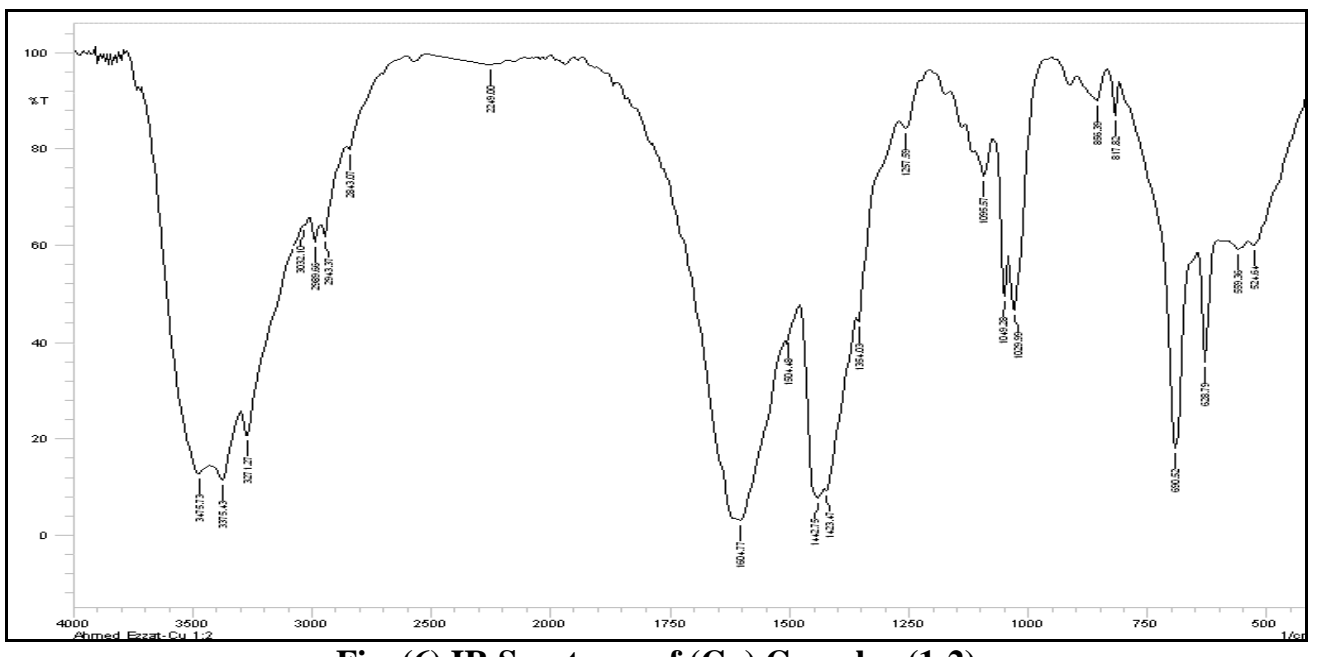

Fig. (6) IR Spectrum of (Cu) Complex (1:2)

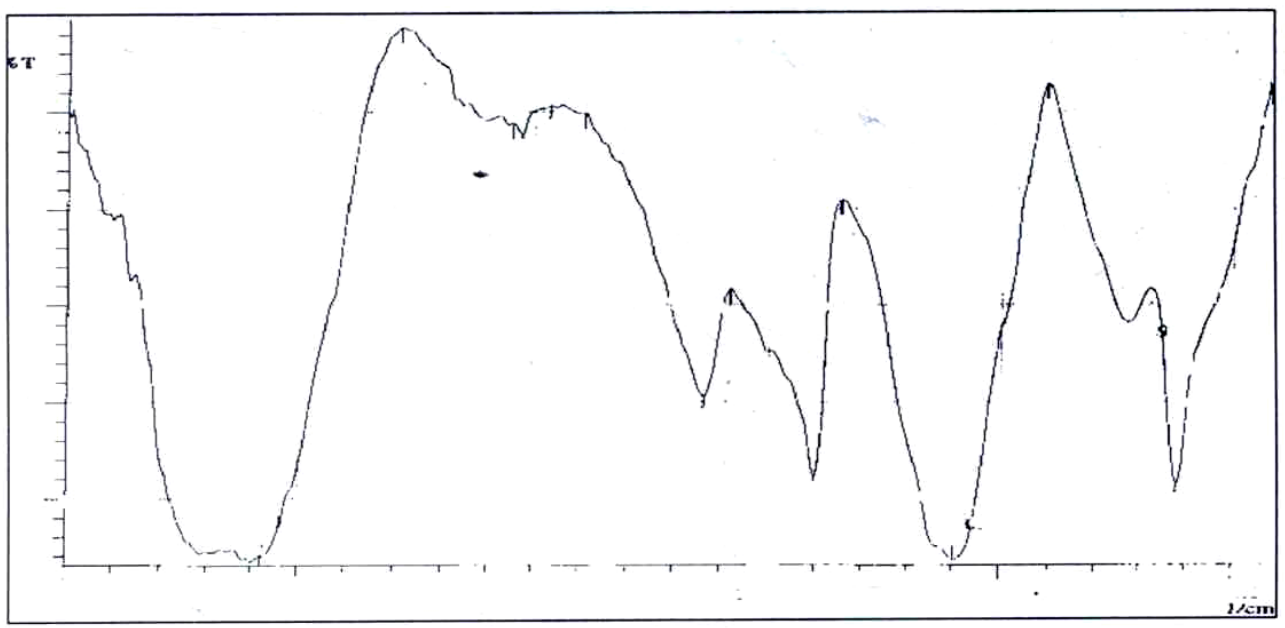

Fig. (7) IR Spectrum of (Ni) Complex (1:2) 


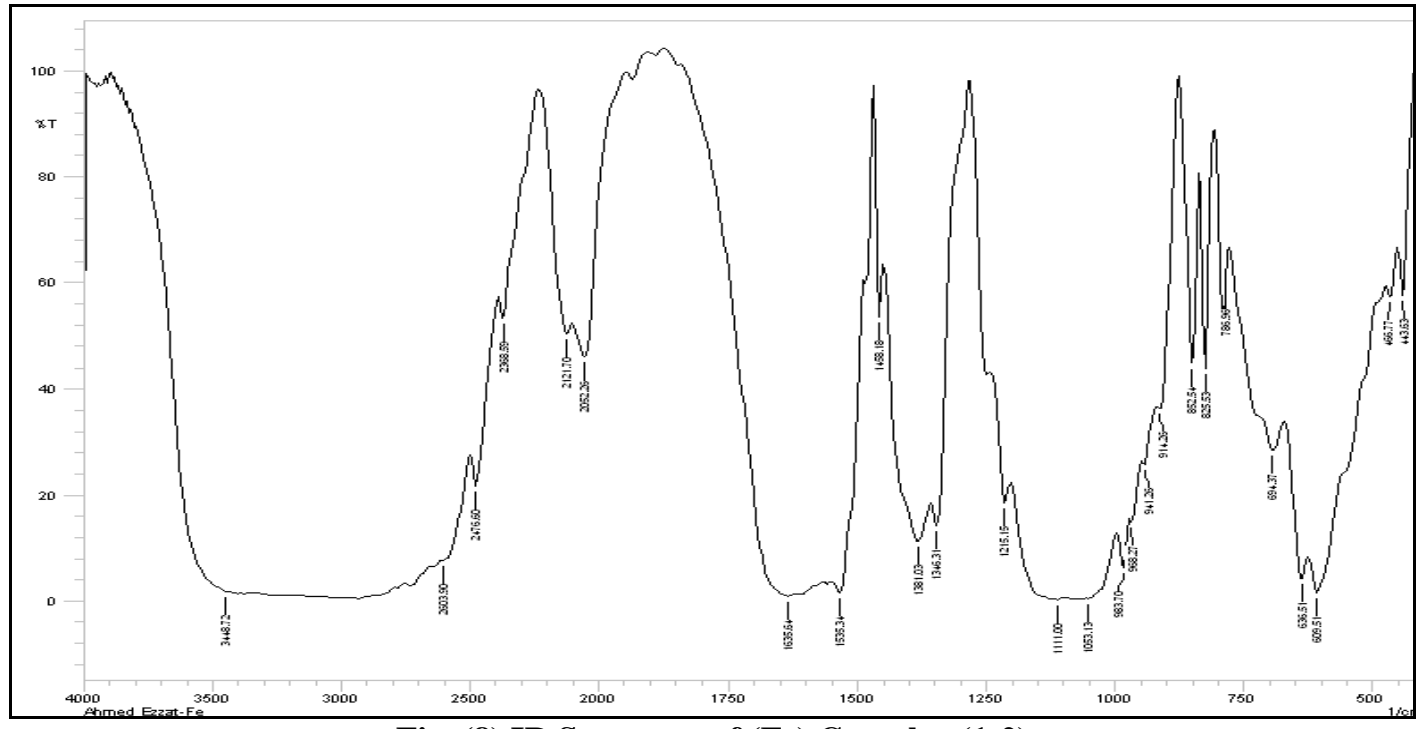

Fig. (8) IR Spectrum of (Fe) Complex (1:2)

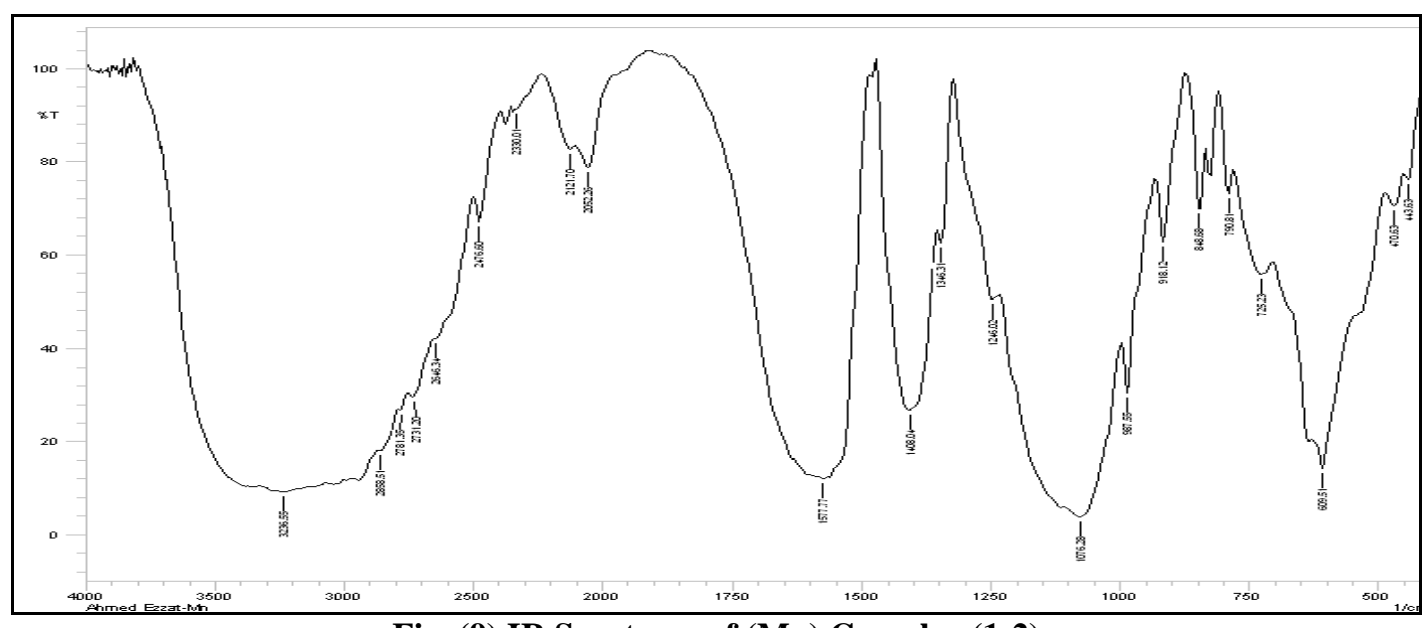

Fig. (9) IR Spectrum of (Mn) Complex (1:2)

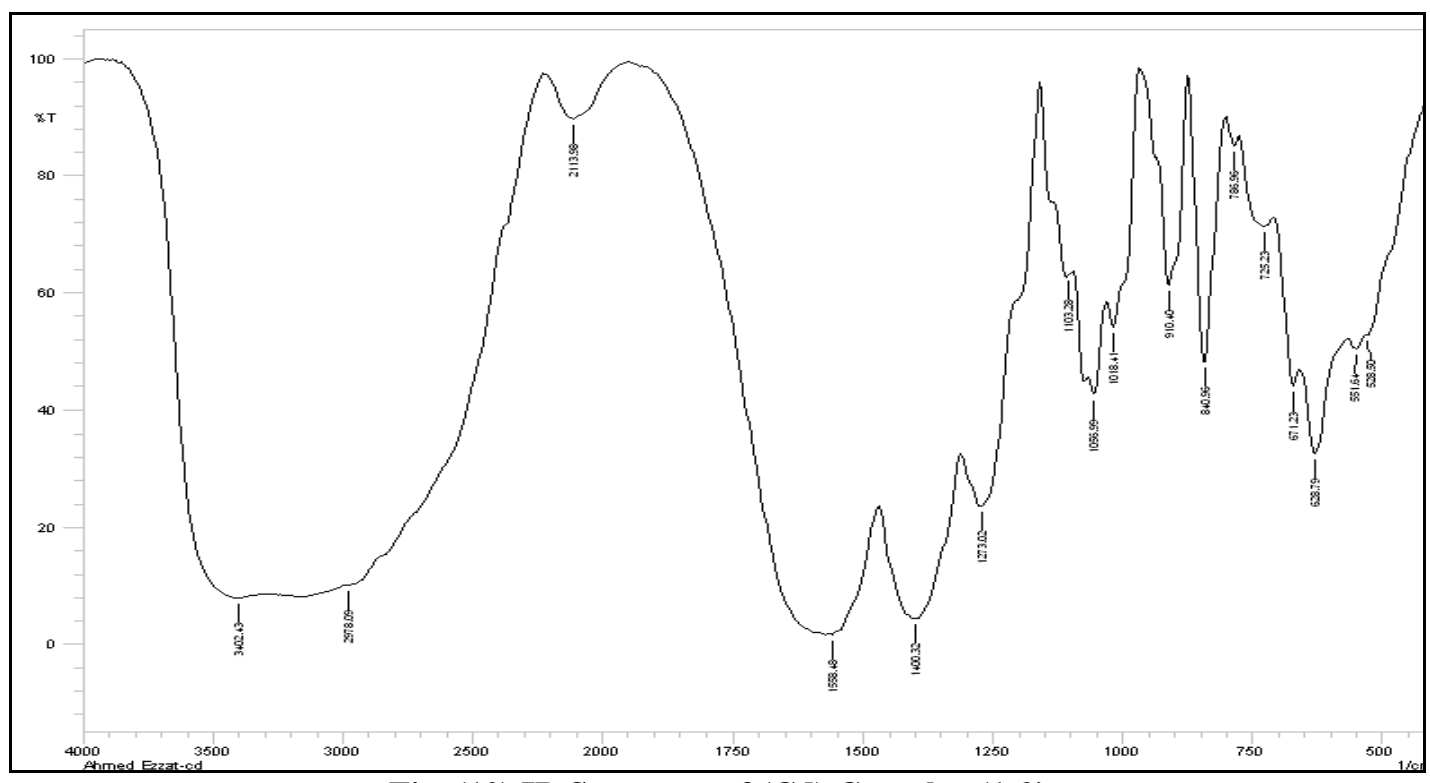

Fig. (10) IR Spectrum of (Cd) Complex (1:2) 


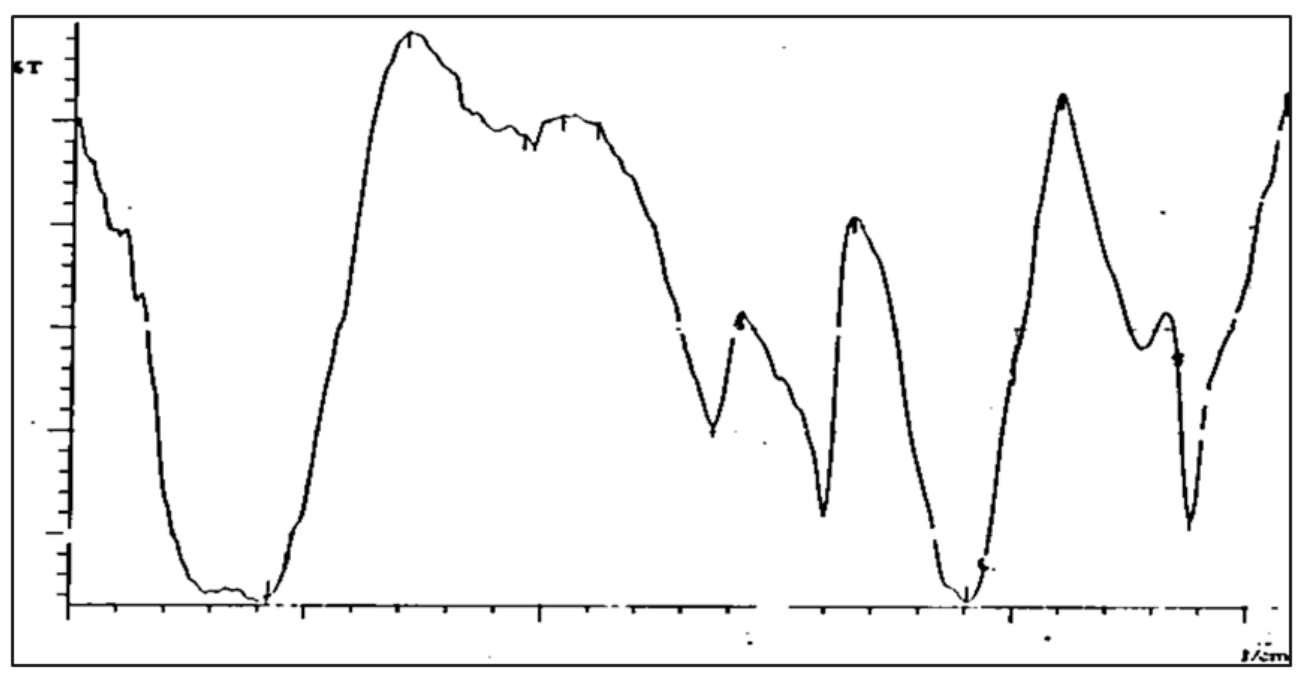

Fig. (11) IR Spectrum of (Pd) Complex (1:2)

The spectrum of ligand showed vast band centered at $3417 \mathrm{~cm}^{-1}$ which assigned to $v(\mathrm{OH})$. but robust wide bands regarded within the $3620-3230$ and $3220-2620 \mathrm{~cm}^{-1}$ tiers affirm the presence of non-equivalent intra and intermolecular hydrogen bondings [27]. the spectrum of ligand displayed two bands at 2990 and $3024 \mathrm{~cm}^{-1}$ assignable to $v\left(\mathrm{CH}_{2}\right)$. also, the spectrum of ligand displayed 3 bands at 1724 , 1615 and $1577 \mathrm{~cm}^{-1}$ assignable to $v(\mathrm{C}=\mathrm{O})$, $v(\mathrm{C}=\mathrm{N})$ respectively [28-31].the mode of bonding of the ligand can be predicted with the aid of assessment the IR spectra of the complexes with that of the loose ligand.The complexes show a huge band within the 3650 $3110 \mathrm{~cm}^{-1}$ range, assigned to the presence of hydrated or coordinated water molecules. however, the bands regarded inside the 3620 $2600 \mathrm{~cm}^{-1}$ variety is because of intra-and intermolecular hydrogen bindings. the $v(\mathrm{NH})$ group appears inside the $3380-3170 \mathrm{~cm}^{-1}$ levels.

The complexes display $v(\mathrm{C}=\mathrm{O})$ and $v(\mathrm{C}=\mathrm{N})$ at $1675-1610 \mathrm{~cm}^{-1}$ range. those bands have been shifted to decrease frequency suggesting the participation of the carbonyl and azomethine agencies in the coordination process. the arrival of function bands at $(1480,1375) \quad, \quad(1453,1352),(1432,1323)$ $(1472,1335)(1448,1335)(1450,1335)(1440$, $1339)$ and $(1447,1343) \mathrm{cm}^{-1}$ inside the spectra of the complexes (1), (2), (3) (4) and(5) have been attributed to vas $\left(\mathrm{COO}^{-}\right)$and $\operatorname{vs}\left(\mathrm{COO}^{-}\right)$ respectively, indicating the participation of the acetate oxygen within the complicated formation [29].

The mode of coordination of acetate institution has often been deduced from the importance of the found separation among the vas $\left(\mathrm{COO}^{-}\right)$and vs(COO-) the separation price $(\Lambda)$ between vasym $\left(\mathrm{COO}^{-}\right)$and vsym $\left(\mathrm{COO}^{-}\right)$for these complexes have been inside the (105-112) $\mathrm{cm}^{-1}$ variety suggesting the coordination of acetate group in a monodentate style [28,29] the spectra of nitrate complexes (6) confirmed vibrations at (1076) $\mathrm{cm}^{-1}$ assigned to coordinated nitrate organization [30]. the mode of coordination is supported with the aid of look of latest bands inside the 630-605 and 590-519 $\mathrm{cm}^{-1}$ regions similar to $v(\mathrm{M}-0)$ and $v$ (M-N) bands respectively [32-33].

The mass spectrum of the ligand showed a molecular ion top at m/e $276.14 \mathrm{amu}$, similar to its method weight (F.W 276.14) and assisting the proposed shape, and the purity of the ligand organized. the prominent mass fragmentation peaks located at $\mathrm{m} / \mathrm{z}=56,70,87,129,147,157$, 175, 203, 231, 252, 354, 417 and $446 \mathrm{amu}$ corresponding to $\mathrm{C}_{4} \mathrm{H}_{8}, \quad \mathrm{C}_{5} \mathrm{H}_{10}, \quad \mathrm{C}_{5} \mathrm{H}_{13} \mathrm{~N}$, $\mathrm{C}_{6} \mathrm{H}_{9} \mathrm{~N}_{3} \mathrm{O}, \mathrm{C}_{6} \mathrm{H}_{11} \mathrm{~N}_{3} \mathrm{O}_{2}, \mathrm{C}_{6} \mathrm{H}_{7} \mathrm{~N}_{4} \mathrm{O}_{2}, \mathrm{C}_{6} \mathrm{H}_{9} \mathrm{~N}_{4} \mathrm{O}_{3}$, $\mathrm{C}_{6} \mathrm{H}_{11} \mathrm{~N}_{2} \mathrm{O}_{4}, \quad \mathrm{C}_{13} \mathrm{H}_{19} \mathrm{~N}_{4}, \quad \mathrm{C}_{14} \mathrm{H}_{14} \mathrm{~N}_{5}, \quad$ moieties respectively and additionally support the advised structure of the ligand. 
The ${ }^{1}$ HNMR spectrum of the 1igand turned into recorded in DMSO- $\mathrm{d}^{6}$. the spectrum of the ligand shows alerts consistent with the proposed structure. the spectrum showed a fixed of peaks as singlet at $4.8-5.4 \mathrm{ppm}$ range which can be assigned to the protons of amine corporations. methylene protons of ch2 group regarded at $2.4-2.8$ ppm range as a singlet peaks which found as more than one.

\section{RESULTS and DISCUSSION: -}

A) Measurement of the Capacity of chelator (Metal Removal Efficiency)

Biosorption capacity $\left(\mathrm{Q}_{\mathrm{e}}\right)$ and the quantity of metallic adsorbed in keeping with gram of biosorbent, can be calculated in $\mathrm{mg} / \mathrm{g}$ as follows: $\mathbf{Q}_{\mathrm{e}}=\left(\mathbf{C}_{\mathbf{o}}-\mathbf{C}_{\mathrm{e}}\right) \mathbf{V} / \mathbf{m}$

In which, $\mathrm{C}_{\mathrm{o}}$ is the preliminary steel ions concentration $(\mathrm{mg} / \mathrm{L}), \mathrm{C}_{\mathrm{e}}$ is the equilibrium awareness of metal ions $(\mathrm{mg} / \mathrm{L}), \mathrm{V}$ is the volume of solution $(\mathrm{L})$ and $\mathrm{m}$ is the mass of biosorbent $(\mathrm{g})$. percentage of steel removal can also be displayed by means of the proportion of steel elimination as follows: metallic removal $(\%)=100\left(C_{0}-C_{e}\right) / C_{0}$

When the chelator is treated with the metal ions in (2:1) molar ratio in Fig (13), we observed the elimination efficiency after 60 $\min \left(70^{\circ} \mathrm{c}\right)$ became as follows: $75 \%$ for $(\mathbf{M n})$, $48 \%$ for $(\mathbf{F e}), 54 \%$ for $(\mathbf{C d}), 76.7 \%$ for $(\mathbf{C u})$, $44 \%$ for $(\mathbf{P b})$ and $57.5 \%$ for $(\mathbf{N i})$.

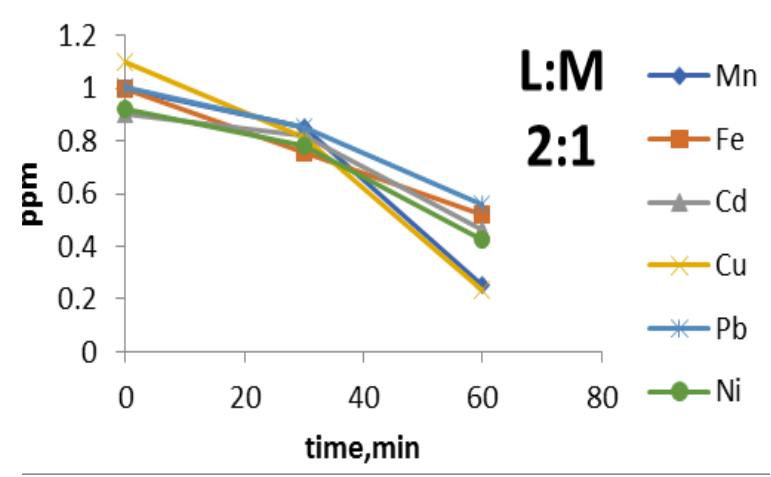

Fig.13: - Variation concentration of heavy metals at molar ratio $(2: 1)$

When the chelator became treated with the metallic ions in (1:2) molar ratio in Fig. (14), we determined the removal efficiency after 60 $\min \left(70^{\circ} \mathrm{c}\right)$ became as follows: $22 \%$ for $(\mathbf{M n})$,
$37.5 \%$ for $(\mathbf{F e}), 15 \%$ for $(\mathbf{C d}), 27.5 \%$ for $(\mathbf{C u})$, $38.5 \%$ for $(\mathbf{P b})$ and $21 \%$ for $(\mathbf{N i})$.

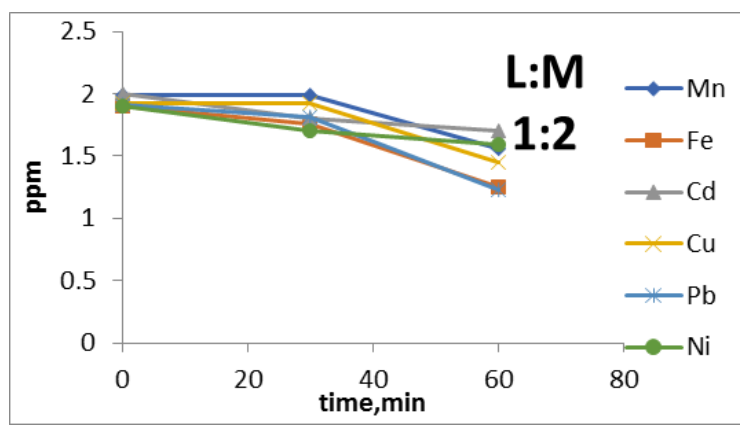

Fig.14: - Variation concentration of heavy metals at molar ratio $(1: 2)$

Whilst the chelator changed into treated with the steel ions in (3:1) molar ratio in Fig. (15) we found the removal performance after $60 \mathrm{~min}\left(70^{\circ} \mathrm{c}\right)$ became as follows $85 \%$ for (Mn), $77 \%$ for $(\mathbf{F e}), 75 \%$ for $(\mathbf{C d}), 87 \%$ for (Cu), $85 \%$ for (pb) and $66 \%$ for $(\mathbf{N i})$.

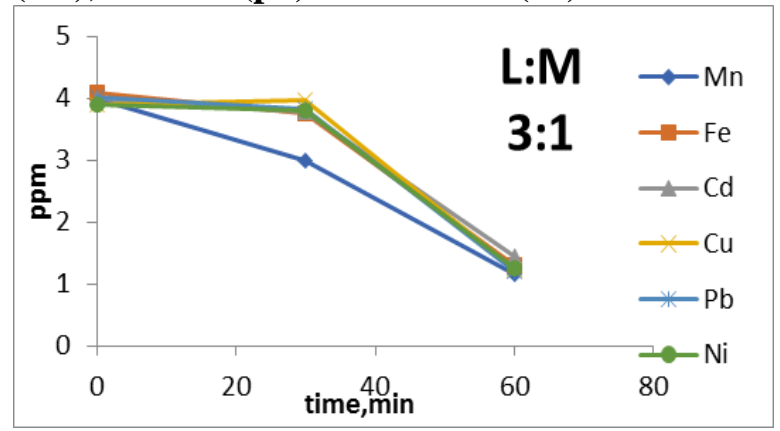

Fig.15: - Variation concentration of heavy metals at molar ratio $(3: 1)$

Whilst the chelator changed into treated with the metallic ions in $\mathbf{( 4 : 1 )}$ molar ratio in Fig. (16), we observed the elimination performance after $60 \mathrm{~min}\left(70^{\circ} \mathrm{c}\right)$ become as follows $100 \%$ for (Mn), $100 \%$ for (Fe), $100 \%$ for $(\mathbf{C d}), 100 \%$ for $(\mathbf{C u}), 100 \%$ for $(\mathbf{P b})$ and $100 \%$ for $(\mathbf{N i})$.

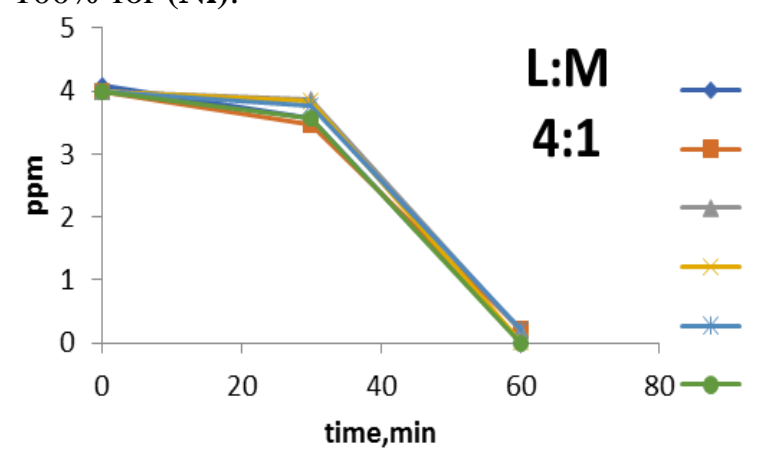

Fig.16: - Variation concentration of heavy metals at molar ratio $(4: 1)$ 


\section{b) DHS Overall Performance as Post- remedy at RHT $6 \mathrm{~h}$ in Absence of Chelator}

Variations within the sorts of wastewater remedy generation and comparison among them using chemical parameters consisting of overall suspended stable (TSS), chemical oxygen demand (COD), organic oxygen call for (BOD) at retention time $6 \mathrm{~h}$ are tested as follows:

\section{The Application of (DHS) System: -}

\section{1-ChemicalOxygen Demand(COD) Removal}

Based on those consequences, the DHS machine is considered an awesome opportunity put up- treatment device. studies completed protected physical factors which include retention time, sponge pore size. The measured cod awareness within the treated effluent of DHS became (35 $\pm 10 \%)$ (Fig.17) high-quality COD removal became swiftly mounted in all of the reactors, that's one of the DHS structures deserves. that is attributed to the brief adsorption of organic substances onto the sponge media. the results obtained indicated that the COD decreases from $45 \%$ in number one effluent to $85 \%$ inside the DHS effluent. this could be attributed to the particulate be counted entrapment and degradation in DHS sponge by means of distinctive feature of its lengthy retention time.

\section{2 -Biological Oxygen Demand (BOD) and TSS Removal}

The elimination performance of bod in DHS was $(30.23 \pm 10 \%)$. The removal efficiency of TSS turned into $(65.10 \pm 12 \%)$ in the DHS system. suspended solids have been entrapped and degraded inside the sponge of the DHS machine as illustrated in (Figs.18\&19).

\section{3- Nitrogen Balance And Removal Efficiency}

Concerning nitrogen elimination, it became discovered that the mode of nitrogen elimination within the DHS reactor is nitrification followed with the aid of denitrification. the nitrified residing in the retained wastewater of DHS reactor turned into shown first convert ammonia to nitrite and nitrate which had been proven first transformed to gaseous nitrogen by using denitrification in the anoxic zone of the sponge cloth. variations in nitrite and nitrate concentrations are shown in Figs. (20 and 21) respectively. nitrate concentrations in the DHS effluent were fluctuated have been among 1.7 and $1.86 \mathrm{mg} / \mathrm{L}$. and nitrite concentrations inside the DHS effluent were fluctuated had been among 1.45 and $1.84 \mathrm{mg} / \mathrm{L}$. nitrification in DHS happened within the lower portion of the reactor where the boom in the nitrate and nitrite may be due to the nitrification via nitrobacteria. (Figs.20\&21)

\section{4 -Fecal Coliform Removal}

Removal of pathogenic organisms is one of the major objectives of municipal wastewater treatment for growing countries because it signifies the hazard factor for public fitness. many countries like Egypt have stringent standards regarding the presence of pathogens in treated wastewater as they directly affect the fitness and sanitation conditions of the populace. ${ }^{[31]}$ inside the gift have a look at, fecal coliform become selected as an indicator for pathogenic organisms. it's far properly understood that anaerobic reactors do now not significantly make a contribution to the removal of coliforms ${ }^{[32]}$. but rather accurate effects were completed the use of the DHS reactor. the geometric mean of fecal coliform be counted within the DHS reactor effluent turned into decreased via $99.9 \%$.

The relatively higher performance may be due to adsorption and bio-filtration of fecal coliform by way of curtain sponge packing in the sedimentation phase of the DHS reactor. furthermore, a giant drop of fecal coliform counts has been pronounced in the final effluent with residual be counted of two hundred MPN/100 $\mathrm{ml}$. these outcomes indicated that the DHS reactor is extra effective for the elimination of fecal coliform in comparison to different previously used cardio systems. ${ }^{[33]}$

It became found that rotating biological contactor (RBC) machine treating home wastewater has accomplished a discount in fecal coliform rely of $99.9 \%$. also, one in all 
likelihood cause of the higher performance of DHS reactor might be the better quantity of retained wastewater and lengthy SRT. in a current observe, ${ }^{[34]}$ the mechanism of fecal coliform removal in DHS reactor effluent turned into investigated. the results showed that the removal efficiency of fecal coliform elimination efficiencies in DHS was

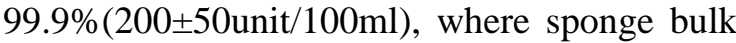
volume changed into discovered to be the most essential elements affecting entrapment of fecal coliform in DHS treating machine. (Fig.22)

The Performance Results of DHS System in Treating Domestic Wastewater at a total HRT of $6 \mathrm{H}$ (Runs 1, 2, 3, 4 and 5)

Table (1): -Run1

\begin{tabular}{|c|c|c|c|c|}
\hline \multirow{2}{*}{ S } & \multirow{2}{*}{ Parameter } & \multirow{2}{*}{ Unit } & \multicolumn{2}{|c|}{ Result } \\
\cline { 4 - 5 } & & & Raw 2 & Run 2 \\
\hline 1 & PH & Unit & 7.21 & 7.55 \\
\hline 2 & TDS & Ppm & 466 & 285 \\
\hline 3 & TSS & Ppm & 135 & 65 \\
\hline 4 & COD & Ppm & 320 & 164 \\
\hline 5 & BOD & Ppm & 180 & 96 \\
\hline 6 & Nitrite $\left(\mathrm{NO}_{2}\right)$ & Ppm & 1.27 & 1.45 \\
\hline 7 & Nitrate $\left(\mathrm{NO}_{3}\right)$ & Ppm & 1.24 & 1.85 \\
\hline 8 & Conductivity & $\mu \mathrm{S} / \mathrm{cm}$ & 585 & 365 \\
\hline 9 & Fecal Coliform & $\mathrm{CFU} / 100 \mathrm{~mL}$ & $2.2 \times 10^{6}$ & $1.12 \times 10^{6}$ \\
\hline
\end{tabular}

Table (2): -Run 2

\begin{tabular}{|c|c|c|c|c|}
\hline \multirow{2}{*}{ S } & \multirow{2}{*}{ Parameter } & Unit & \multicolumn{2}{|c|}{ Result } \\
\cline { 4 - 5 } & & & Raw 1 & Run 1 \\
\hline 1 & PH & Unit & 7.01 & 7.25 \\
\hline 2 & TDS & Ppm & 506 & 376 \\
\hline 3 & TSS & Ppm & 150 & 76 \\
\hline 4 & COD & Ppm & 300 & 145 \\
\hline 5 & BOD & Ppm & 175 & 108 \\
\hline 6 & Nitrite $\left(\mathrm{NO}_{2}\right)$ & $P p m$ & 1.42 & 1.88 \\
\hline 7 & Nitrate $\left(\mathrm{NO}_{3}\right)$ & $\mathrm{Ppm}$ & 1.6 & 1.77 \\
\hline 8 & Conductivity & $\mu \mathrm{S} / \mathrm{cm}$ & 662 & 455 \\
\hline 9 & Fecal Coliform & $\mathrm{CFU} / 100 \mathrm{~mL}$ & $4.25 \times 10^{6}$ & $2.5 \times 10^{6}$ \\
\hline
\end{tabular}

Table (3): -Run 3

\begin{tabular}{|c|c|c|c|c|}
\hline \multirow{2}{*}{ S } & \multirow{2}{*}{ Parameter } & \multirow{2}{*}{ Unit } & \multicolumn{2}{|c|}{ Result } \\
\cline { 4 - 5 } & & & Raw 3 & Run 3 \\
\hline 1 & $\mathrm{PH}$ & Unit & 7.5 & 7.52 \\
\hline 2 & $\mathrm{TDS}$ & $\mathrm{Ppm}$ & 345 & 218 \\
\hline 3 & $\mathrm{TSS}$ & $\mathrm{Ppm}$ & 148 & 76 \\
\hline 4 & $\mathrm{COD}$ & $\mathrm{Ppm}$ & 335 & 145 \\
\hline 5 & BOD & $\mathrm{Ppm}$ & 210 & 102 \\
\hline 6 & Nitrite $\left(\mathrm{NO}_{2}\right)$ & $\mathrm{Ppm}$ & 1.2 & 1.46 \\
\hline 7 & Nitrate $\left(\mathrm{NO}_{3}\right)$ & $\mathrm{Ppm}$ & 1.44 & 1.67 \\
\hline 8 & Conductivity & $\mu \mathrm{S} / \mathrm{cm}$ & 415 & 256 \\
\hline 9 & Fecal Coliform & $\mathrm{CFU} / 100 \mathrm{Ml}$ & $3.2 \times 10^{6}$ & $1.54 \times 10^{6}$ \\
\hline
\end{tabular}

Table (4): -Run 4

\begin{tabular}{|c|c|c|c|c|}
\hline \multirow{2}{*}{ S } & \multirow{2}{*}{ Parameter } & \multirow{2}{*}{ Unit } & \multicolumn{2}{|c|}{ Result } \\
\cline { 3 - 5 } & & & Raw 4 & Run 4 \\
\hline 1 & PH & Unit & 7.03 & 7.21 \\
\hline 2 & TDS & Ppm & 482 & 420 \\
\hline 3 & TSS & Ppm & 170 & 74 \\
\hline 4 & COD & Ppm & 380 & 268 \\
\hline 5 & BOD & Ppm & 230 & 162 \\
\hline 6 & Nitrite $\left(\mathrm{NO}_{2}\right)$ & Ppm & 1.21 & 1.26 \\
\hline 7 & Nitrate $\left(\mathrm{NO}_{3}\right)$ & Ppm & 1.20 & 1.40 \\
\hline 8 & Conductivity & $\mu \mathrm{SS} / \mathrm{cm}$ & 660 & 440 \\
\hline 9 & Fecal Coliform & $\mathrm{CFU} / 100 \mathrm{~mL}$ & $4 \times 10^{6}$ & $2 \times 10^{6}$ \\
\hline
\end{tabular}

Table (5): -Run 5

\begin{tabular}{|c|c|c|c|c|}
\hline \multirow{2}{*}{ S } & \multirow{2}{*}{ Parameter } & \multirow{2}{*}{ Unit } & \multicolumn{2}{|c|}{ Result } \\
\cline { 3 - 5 } & & & Raw 1 & Run 1 \\
\hline 1 & PH & Unit & 7.90 & 7.21 \\
\hline 2 & TDS & Ppm & 480 & 425 \\
\hline 3 & TSS & Ppm & 195 & 123 \\
\hline 4 & COD & Ppm & 317 & 200 \\
\hline 5 & BOD & Ppm & 180 & 119 \\
\hline 6 & Nitrite $\left(\mathrm{NO}_{2}\right)$ & Ppm & 1.38 & 1.86 \\
\hline 7 & Nitrate $\left(\mathrm{NO}_{3}\right)$ & Ppm & 0.60 & 1.84 \\
\hline 8 & Conductivity & $\mu \mathrm{S} / \mathrm{cm}$ & 580 & 370 \\
\hline 9 & Fecal Coliform & $\mathrm{CFU} / 100 \mathrm{~mL}$ & $2 \times 10^{6}$ & $3 \times 10^{5}$ \\
\hline
\end{tabular}




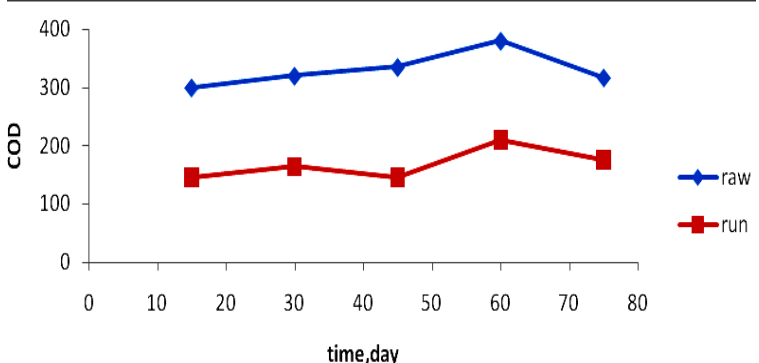

Fig.17: - Variation in total COD along DHS treatment system

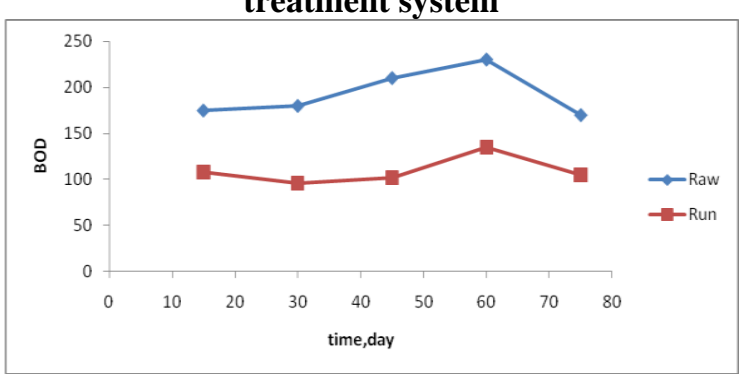

Fig.18: - BOD total variation along DHS treatmentsystem

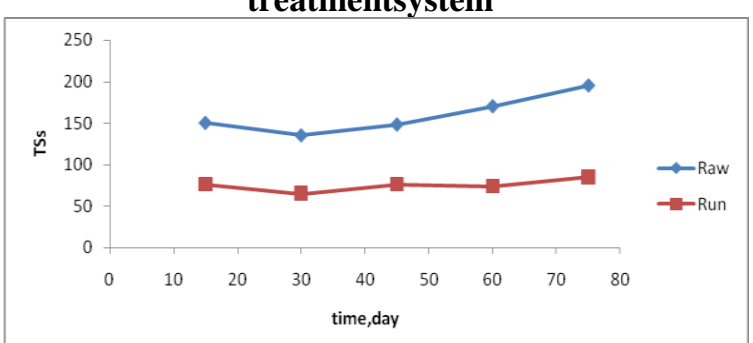

Fig.19: - Variation in TSS along DHS treatment system

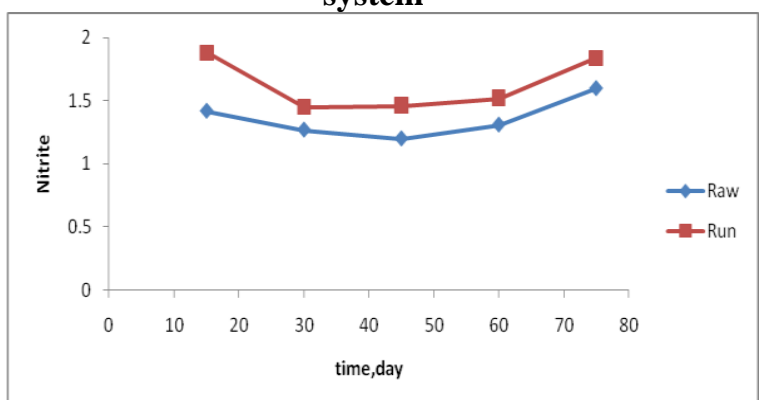

Fig.20: - Variation in nitrite $\left(\mathrm{NO}_{2}\right)$ along DHS treatment system

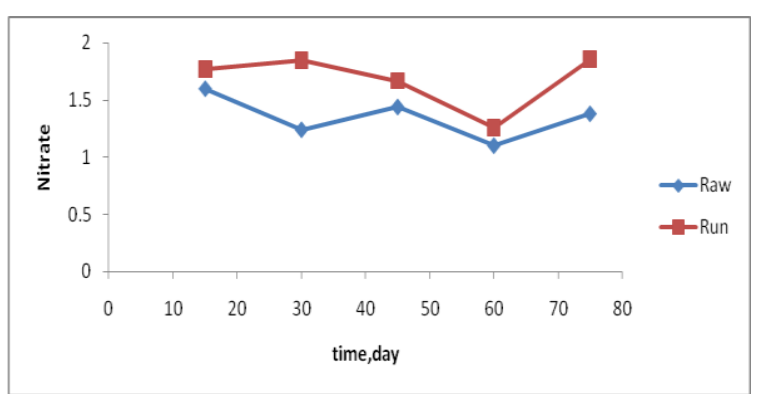

Fig.21: - Variation in nitrate (NO) along DHS treatment system

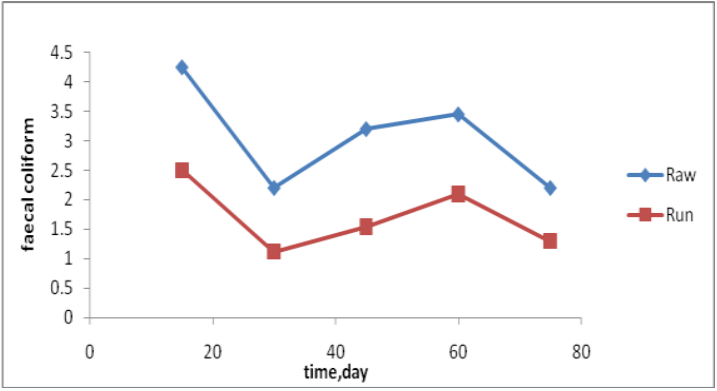

Fig.22: - Variation in Fecal Coliform along DHS treatment system

The Performance Results of Heavy Metals Removal at $\left(0.7 \mathrm{~g} / \mathrm{l}\right.$ of and $1.4 \mathrm{gL}^{-1}$ from The Chelator) as Illustrated in Tables (6 and 7) and Figs. (14, 15)

Table (6) : (0.7gL-1ofchelator)

\begin{tabular}{|c|c|c|c|c|}
\hline \multicolumn{2}{|c|}{ Parameters } & Unit & Raw & Run \\
\hline \multirow{6}{*}{$\begin{array}{l}\text { Heavy } \\
\text { metals }\end{array}$} & $\mathrm{Cu}$ & $\mathrm{mgL}^{-1}$ & 0.213 & 0.089 \\
\hline & $\mathrm{Mn}$ & $\mathrm{mgL}^{-1}$ & 0.102 & $\leq 0.01$ \\
\hline & $\mathrm{Cd}$ & $\mathrm{mgL}^{-1}$ & 0.174 & 0.064 \\
\hline & $\mathrm{Ni}$ & $\mathrm{mgL}^{-1}$ & 0.562 & 0.245 \\
\hline & $\mathrm{Fe}$ & $\mathrm{mgL}^{-1}$ & 1.148 & 0.115 \\
\hline & $\mathrm{Pb}$ & $\mathrm{mgL}^{-1}$ & 0.146 & 0.031 \\
\hline \multicolumn{2}{|c|}{ Fecal Coliform } & unit/100ml & $2.4 \times 10^{5}$ & $3.2 \times 10^{3}$ \\
\hline
\end{tabular}

Table (7) : $\left(1.4 \mathrm{gL}^{-1}\right.$ of chelator $)$

\begin{tabular}{|c|c|c|c|c|}
\hline \multicolumn{2}{|l|}{ Parameters } & Unit & Raw & Run \\
\hline \multirow{4}{*}{$\begin{array}{l}\text { Heavy } \\
\text { metals }\end{array}$} & $\mathrm{Cu}$ & $\mathrm{mgL}^{-1}$ & 0.213 & 0.089 \\
\cline { 2 - 5 } & $\mathrm{Mn}$ & $\mathrm{mgL}^{-1}$ & 0.102 & $\leq 0.01$ \\
\cline { 2 - 5 } & $\mathrm{Cd}$ & $\mathrm{mgL}^{-1}$ & 0.174 & 0.064 \\
\cline { 2 - 5 } & $\mathrm{Ni}$ & $\mathrm{mgL}^{-1}$ & 0.562 & 0.245 \\
\cline { 2 - 5 } & $\mathrm{Fe}$ & $\mathrm{mgL}^{-1}$ & 1.148 & 0.115 \\
\cline { 2 - 5 } & $\mathrm{Pb}$ & $\mathrm{mgL}^{-1}$ & 0.146 & 0.031 \\
\hline \multicolumn{2}{|c|}{ Fecal Coliform } & unit/100ml & $2.4 \times 10^{5}$ & $3.2 \times 10^{3}$ \\
\hline
\end{tabular}

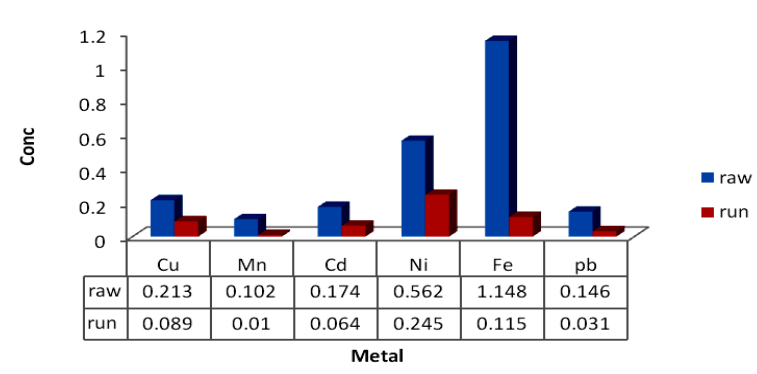

Figs. (23): Variation in Heavy Metals Concentrations along Raw and Treated Wastewater. 


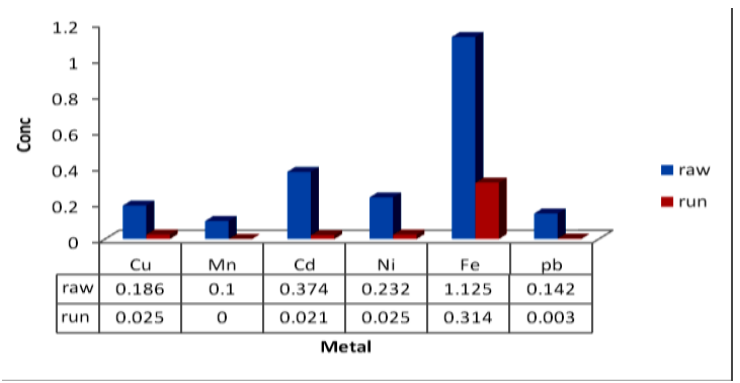

Figs. (24): Variation in Heavy Metals Concentrations along Raw and Treated Wastewater.

5 -DHS Performance as Post-Treatment at RHT (3H) in presence of Chelator (at $0.7 \mathrm{gl}^{-}$ fromtheChelator)

\section{Heavy Metals Removal Efficiency}

The received effects showed that the residual values of $(\mathbf{C u})$ while dealt with chelator decrease from 0.213 to $0.089 \mathrm{mgl}^{-1}$ $(58.2 \%)$, while these of $(\mathbf{M n})$ decreases from 0.102 to $0.01 \mathrm{mgl}^{-1}(90.19 \%)$, for $(\mathbf{C d})$ they lower from 0.174 to $0.064 \mathrm{mgl}^{-1}$ (63.21\%),for (Ni) they lower from 0.562 to $0.245 \mathrm{mgl}^{-1}$ $(56.40 \%)$,for $(\mathbf{F e})$ they lower from 1.148 to $0.115 \mathrm{mgl}^{-1}(90 \%)$,for $(\mathbf{P b})$ they lower from 0.146 to $0.031 \mathrm{mgl}^{-1}(78.7 \%)$. debris of heavy metals need to be absorbed or adsorbed and captured inside the surface of the chelator surface location. debris to be digested it need to be captured first and the digestion and the biodegradation processes might be then coming about inside the land. to be had statistics indicate good performance of the chelator in regard to heavy metals removal efficiency.

\section{Bacterial Treatment}

The received consequences confirmed that, the residual values of fecal coliform whilst dealt with chelator, the amount decreases from $2.4 \times 10^{5}$ to $3.2 \times 10^{3} \mathrm{MPN}$ index $/ 100 \mathrm{ml}$ (99.99\%).

\section{6 -DHS Performance as Post-Treatmentat RHT 3hin Presence of Chelator (at Dose 1.4 gl $^{-1}$ fromthe Chelator)}

\section{Heavy Metals Removal Efficiency}

The results showed that the residual values of heavy metals become observed as: $(86.55 \%)$ for $(\mathbf{C u})$ while handled with chelator, the amount decreases from 0.186 to $0.0 .5 \mathrm{mgl}^{-1}$, $(100 \%)$ for $(\mathbf{M n})$ decreases from 0.10 to zero $\mathrm{mgl}^{-1},(74.38 \%)$ for $(\mathbf{C d})$ decreases from 0.374 to $0.021 \mathrm{mgl}^{-1},(89.2 \%)$ for $(\mathbf{N i})$ decreases from 0.232 to $0.025 \mathrm{mgl}^{-1}$, (72.08\%) for $(\mathbf{F e})$ decreases from 1.125 to $0.314 \mathrm{mgl}^{-1}$, $(97.88 \%)$ for $(\mathbf{P b})$ decreases from 0.142 to $0.003 \mathrm{mgl}^{-1}$.

\section{Bacterial Treatment}

The result confirmed that the residual values of fecal coliform became (99.99\%) whilst dealt with ligand has decreased from $5.2 \times 10^{6}$ to $200 \mathrm{MPN}$ index $/ 100 \mathrm{ml}$.

\section{CONCLUSION:}

Improvement of the satisfactory of water handled (with low value) is wanted to be useful it in agriculture that can be finished thru one of a kind approaches as protection water. on this have a look at, DHS was used for direct remedy of wastewater separately and inside the presence of chelator in terms of removal of COD, BOD, TSS and TDS at fixed hydraulic retention time ( $6 \mathrm{~h}$ and $3 \mathrm{~h}$ ) based totally at the sponge quantity. this have a look at confirmed top notch decrease in cod and bod (as much as $95 \%$ ). the observe showed additionally that the smaller the sponge sizes of the DHS reactor, the better can be the elimination efficiencies. so, DHS can be used efficaciously in small villages that cannot meat provider by means of wastewater network as secondary remedy.

\section{REFERENCES}

[1] Nemerow, N.; Dasgupta, A. Industrial and Hazardous Waste Treatment, Van Nostrand Reinhold: New York, 1991.

[2] Tchobanoglous, G; Franklin, L. B. Wastewater Engineering: Treatment, Disposal and Reuse; McGraw Hill, Inc.: New York, 1991.

[3] Kassab, G., Halalsheh, M., Klapwijk, A., Fayyad, M., Van Lier, J.B. Sequential anaerobic-aerobic treatment or domestic wastewater- A review. Bio resource Technology, 101: 3299-3310 (2010).

[4] Ali, I.; Aboul-Enein, H. Y.Chiral Pollutants: Distribution, Toxicity and Analysis by Chromatography and Capillary Electrophoresis; John Wiley \& Sons: Chichester, UK, 2004.

[5] Franklin, L. B. Wastewater Engineering: Treatment, Disposal and Reuse, McGraw Hill Inc.: New York, (1991). 
[6] Okubo, T., Onodera, T., Uemura, S., Yamaguchi, T., Ohashi, A., Harada, H. Bioresource Technology 194: 156-164 (2015).

[7] Droste, R. L. Theory and Practice of Water and Waste water Treatment; John Wiley \& Sons: New York, 1997.

[8] John, D. Z.H and book of Drinking Water Quality: Standards and Controls, Van Nostr and Reinhold: New York, 1990.

[9] Laws, E. A. Aquatic Pollution: An Introductory Text, 3rd ed.; John Wiley \& Sons: New York, 2000.

[10] Ali, I.; Aboul-Enein, H. Y. Instrumental Methods in Metal Ions Speciation: Chromatography, Capillary Electrophoresis and Electrochemistry; Taylor \& Francis Ltd.: New York, 2006.

[11] Onodera, T., Matsunaga, K., Kubota, K., Taniguchi, R., Harada, H., Syutsubo, K., Okubo, T., Uemura, S., Araki, N., Yamada, M., Yamauchi, M., Yamaguchi, T.Bioresource Technology, 136:169-175 (2013).

[12] Ali, I.; Aboul-Enein, H. Y.; Gupta, V. K.Nano Chromatography and Capillary Electrophoresis: Pharmaceutical and Environmental Analyses; John Wiley \& Sons: Hoboken, NJ, 2009.

[13] Vettorazzi, G. International Regulatory Aspects for PesticideChemicals; CRC Press Inc.: Boca Raton, FL; Vol. 1, p14 (1979).

[14] Duffus, J. H.Pure Appl. Chem., 74, 793- 2002.

[15] Zhu, C.; Luan, Z.; Wang, Y.; Shan, X.Sep. Purif. Technol.,57, 161-2007.

[16] Marin, A. B. P.; Zapata, V. M.; Orturao, J. F.; Aguilar, M.; Saez, J.; Lloren, M. J. Hazard. Mater., 139, 122- 2007.

[17] Zhang, F. S.; Nriagu, J. O.; Itoh, H.Water. Res., 39, 389- 2005.

[18] Ruiz, C. G.Bioresour. Technol., 97, 19072006.

[19] Bayramoglu, G.; Arica, M. Y.J. Hazard. Mater., 144, 449- 2007.

[20] Sigel, H.; Sigel, A. Concepts on Metal Ion Toxicity; Marcel Dekker, Inc.: New York, 1986.

[21] Onodera, T., Tandukar, M., Sugiyana, D., Umbra, S., Ohashi, A., Harada, H. Bioresource Technology, 152: 93-100(2014a).

[22] Smiciklas, I.; Dimovic, S.; Plecas, I.; Mitrio, M.Water. Res.,40, 2267- 2006.

[23] Vatistas, N.; Bartolozzi, M.J. Power Sources, 79, 199 - 1999.

[24] Weng, C. H.; Huang, C. P.Colloids Surf., 247, 137-A2004.

[25] Oren, A. H.; Kaya, A.J. Hazard. Mater, 131, 59 -2006 .
[26] Kross, B. C.; Ayebo, A. D.; Fuortes, L. J. Am. Fam. Physician, 46, 183-1992.

[27] Guidelines for Drinking-Water Quality, 2nd ed.; World Health Organization: Geneva, Vol.11993.

[28] Meyers, R. A., Ed. Encyclopedia of Environmental Pollution and Clean-up; John Wiley \& Sons: New York, (1999).

[29] Damia, B., Ed. Emerging Organic Pollutants in Waste Waters and Sludge; Springer: New York, 2005.

[30] Persistent Organic Pollutants: Impact on Child Health; NLM classification: WA 671, WHO report; World Health Organization: Geneva, 2010.

[31] Kohler, A.; Hellweg, S.; Escher, B. I.; Hungerbuhler, K.Environ.Sci. Technol., 40, 3395-2006.

[32] Gadd, G. M.; Griffiths, A. J. Microb. Ecol, 4, 303-1978.

[33] Gledhill, W. E.Toxicol. Assess. 2, 89-1987.

[34] Dyson, T. Population and Food: Global Trends and Future Prospects; Routledge: London, (1996).

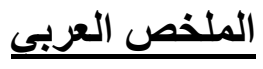

في هذا البحث الخاص باستخدام المرشحات الأسفنجية

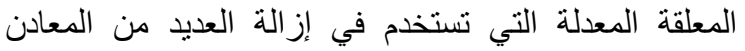

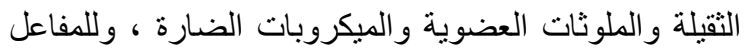
مزايا كثيرة مثل التكلفة المنخفضة وسهولة المانكودانة الاستخدام ومستوى الرضا. من أجل تحقيق هذه الأهداف ، ولقد تم

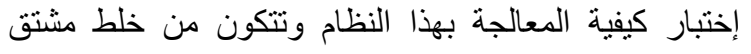

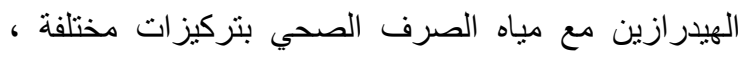

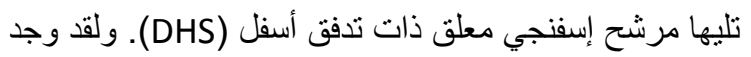
أن القيم المتبقية من المعادن الثقيلة هي كمية من (المنجنيز)

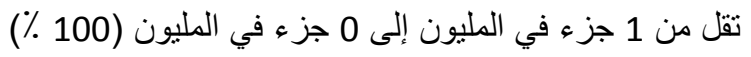

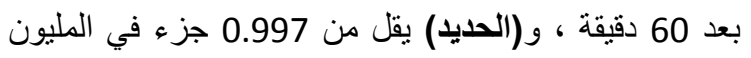

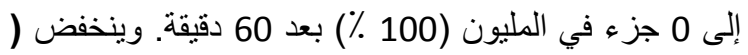

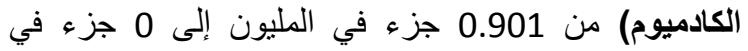

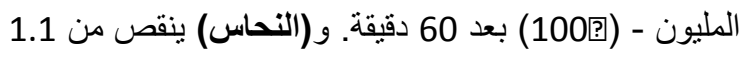

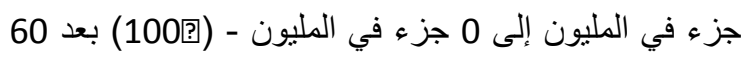
دقيقة. وينخفض (الرصاص) من 1.004 جزءةًا في المليون

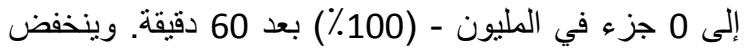
(النيكل) من 0.922 جزء في المليون إلى 0 جزء جزء في المليون - (100 \%) بعد 60 دقيقة. وأوضحت الدر اسات البيولوجية إزالة كبيرة للبكتيريا القولونية حيث انخفض عدد البه البكتيريا

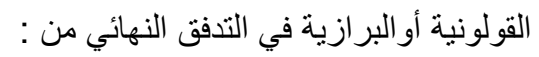

5.2 × $10^{6} \rightarrow 200$ MPN (99.99\%) 